\title{
An Observational Study on Activity Analysis of Nursing Personnel Working in Pediatric In-patient Unit of a Selected Hospital in Delhi
}

\author{
Neeraj ${ }^{1}$, Bindu Shaiju' ${ }^{2}$, Shilpi Sarkar ${ }^{3}$ \\ Abstract
}

\begin{abstract}
The activities of nurses in wards are different throughout the day as the needs of the children vary with the time of the day. Time spent by nurses in direct care activities has been identified as a determinant of better patient outcome and fewer errors. ${ }^{1,2}$ Patient satisfaction is also related to the amount of care received. Role of nurses working in pediatric wards are multifaceted as the needs of a hospitalized child are different from an older patient. Information about the amount of time spent on various activities is very important for the nurse manager. It provides them with evidence to maximize productivity by evaluating the appropriate staff development; skill-mix and whether they need job re-allocation and changes in the model of delivery care. Information is needed for evaluating changes in nursing practice following the introduction of new system and to assess effectiveness of the new system. The present study aimed to analyze the activity of nursing personnel working in pediatric in-patient units. The objectives of the study were to assess the proportion of time spent by nursing personnel in various activities in pediatric inpatient units and to compare the proportion of duty time spent by nursing personnel in various activities in different duty shifts. The activities of 41 nursing personnel working in pediatric wards of Sanjay Gandhi Memorial Hospital, New Delhi, comprised the sample. An observation checklist was used to analyze the activities. Total 1511 activities were observed during seven days period in the pediatric units, using the work sampling method. Findings showed that most of the nurse participants were engaged in direct care activities (53\%), followed by indirect care activities (28\%), miscellaneous activities (14\%) and least common were unit related activities (5\%). Medication, documentation, reporting was the most time-consuming activity in the pediatric wards. The proportion of time spent in all groups of activities were different in morning and evening and time spent for direct care and indirect care was same in the pediatric wards. The nursing personnel in pediatric ward spent most of the time in direct care patient activities more than indirect care patient activities. And the least common time was spent in unit-related activities in pediatric in-patient units in both the duty shifts.
\end{abstract}

Keywords: Direct patient care, Indirect patient care, Work sampling, Activity analysis

\section{Background}

Nurse, the frontline caregiver, represents critical and costly resources. ${ }^{3}$ Cost-effective nursing care, staffing levels and adequate skill mix are significant in meeting patient care needs. It also provides the evidence to maximize productivity by evaluating appropriateness of staff development and skill mix such as patient care nursing activities, unit-related activities and personal activities.

${ }^{1}$ M.Sc. Student, ${ }^{2}$ Assistant Professor, ${ }^{3}$ Tutor, Rufaida College of Nursing, Jamia Hamdard, New Delhi.

Correspondence: Bindu Shaiju, Rufaida College of Nursing, Jamia Hamdard, New Delhi.

E-mail Id: bindushaiju07@yahoo.co.in

Orcid Id: http://orcid.org/0000-0002-2574-9160

How to cite this article: Neeraj, Shaiju B, Sarkar S. An Observational Study on Activity Analysis of Nursing Personnel Working in Pediatric In-patient Unit of a Selected Hospital in Delhi. Int J Nurs Midwif Res 2017; 4(3): 35-41.

Digital Object Identifier (DOI): https://doi.org/10.24321/2455.9318.201730

ISSN: $2455-9318$ 
The activities of nurses working in pediatric ward clearly include many aspects of direct patient care such as medication administration, monitoring, carrying out procedure, providing personal hygiene care, assisting with the bladder and bowel eliminations, admission and discharge counselling, etc. Indirect activities performed by nurses in pediatric ward include documentation, reporting, billing, helping in investigations, preparing for procedure, etc. In addition to these, there are unit-related activities such as material management, ward maintenance, housekeeping, supervision, etc. Nursing activities of each unit changes according to the patient's condition. The activities performed by the nurses in any unit can be broadly divided into direct patient care activities, indirect patient care activities, unit-related activities and miscellaneous activities. How health workers spend their working time is of interest to health services. Time spent on various activities is important such as medication, monitoring of the child, assisting in procedure documentation, reporting etc. ${ }^{4,5}$ It provides them with evidence to maximize productivity by evaluating the appropriate staff development; skill mix and whether there is need for job re-allocation and changes in the model of delivery care. Information is needed for evaluating changes in nursing practice following the introduction of new system and to assess the new system effectiveness. ${ }^{6}$

Abbe et al. conducted a study to describe and analyze the work activities of bedside Intensive care unit (ICU) nurses during the day shift. ${ }^{7}$ Just over 76 hours of observation occurred over 10 days and 3081 activities were documented at that time. The major activity groups for the ICU nurses were: 'direct care'. 1857 activities and $40.5 \%$ of the time. 'Indirect care' 986 activities and $32.4 \%$ of the time, "personal" activities 140 activities and $21.9 \%$ of their time and "unit-related" 98 activities and 5.0\% of their time. The ICU nurses undertook two activities simultaneously for $43 \%$ of the study time frame.

\section{Aim}

The aim of this study was to analyze the activities of nursing personnel working in pediatric in-patient units.

\section{Objectives}

- $\quad$ To assess the proportion of time spent by nursing personnel in various activities in pediatric in-patient units.

- $\quad$ To compare the proportion of time spent by nursing personnel in various activities in different duty shifts.

\section{Methods and Materials}

The present study was aimed to analyze the activity of nursing personnel working in pediatric in-patient units. A quantitative non-experimental research approach was found appropriate and most suitable for the study and a cross-sectional research design was adopted for the study. The study was conducted on 41 nursing personnel working in pediatric wards of Sanjay Gandhi Memorial Hospital, New Delhi. The activities of 41 nursing personnel working in pediatric wards of Sanjay Gandhi Memorial Hospital, New Delhi, comprised the sample. Convenience sampling technique was used to obtain the samples. The tool had three sections: Section-1: Demographic data sheet eliciting the demographic details of the participants; Section-2: Guidelines code for nursing activities. The nursing activities were grouped into direct patient care activities, indirect patient care activities, unit-related activities and miscellaneous activities; Section-3: Observation checklist. Tools were developed based on the manual "Guide to the study of activities of health personnel in hospital". The content validity of the tool was established with suggestion and necessary modification from five experts from different fields of nursing and administration. The reliability was established by inter-observer method. Reliability of tool was found to be 0.88 .

After getting ethical permission from Jamia Hamdard Institutional Review Board, formal administrative approval was obtained from the concerned authority of the selected setting to conduct the final study. All the nurses working in the study setting, who met the inclusion criteria, were enrolled into the study. Demographic data was collected with the help of demographic data sheet. Activities were observed by participant observation method. The activities of all the nursing personnel on duty were recorded every half hour. There were 26 observations in hours in two shifts for each staff on duty. For morning shift, observation was made from 8 am to $2 \mathrm{pm}$. The activities were observed from $2 \mathrm{pm}$ to $8 \mathrm{pm}$ in the evening shift. The observations were recorded by the researcher. Descriptive analysis (frequency, percentage and proportion) was done for calculating the time spent in different activities. 


\section{Results}

Sample Demographic Characteristics

Table 1.Frequency and Percentage Distribution of Study Participants by Their

Demographic Characteristics

\begin{tabular}{|c|c|c|}
\hline \multicolumn{2}{|c|}{$\mathrm{n}=41$} \\
\cline { 2 - 3 } Demographic Characteristics & Frequency & Percentage \\
\hline Age of the staff & & 41.46 \\
\hline $20-25$ years & 17 & 14.63 \\
\hline $25-30$ years & 6 & 43.90 \\
\hline 30 years and above & 18 & 14.63 \\
\hline Gender & 6 & 85.36 \\
\hline Male & 35 & \\
\hline Female & & 58.53 \\
\hline Qualification & 24 & 17.07 \\
\hline DGNM & 7 & 9.75 \\
\hline B.Sc. & 4 & 14.63 \\
\hline M.Sc. & 6 & 75.60 \\
\hline B.Sc.(PC) & & 24.39 \\
\hline Nature of Job & 31 & \\
\hline Permanent & 10 & \\
\hline Contractual & & \\
\hline
\end{tabular}


Proportion of Time Spent by Nurses in Different Nursing Activities

Table 2.Frequency and Proportion of Various Activities of Study Participants in the Pediatric In-patient Units

\begin{tabular}{|c|c|c|c|c|c|}
\hline $\begin{array}{l}\text { Group Of } \\
\text { Activities }\end{array}$ & Activities & Frequency & Average & $\begin{array}{c}\text { Relative Time } \\
\text { Proportion (hours) }\end{array}$ & $\begin{array}{c}\text { Total Time } \\
\text { Proportion (\%) }\end{array}$ \\
\hline \multirow{14}{*}{$\begin{array}{l}\text { Direct Activities } \\
\text { (Code no. 1-14) }\end{array}$} & Administration of medication & 115 & .91 & .27 & 53 \\
\hline & Monitoring of child & 139 & 1.10 & .33 & \\
\hline & Feeding through the tube & 67 & .53 & .15 & \\
\hline & Performing procedure & 8 & .06 & .02 & \\
\hline & $\begin{array}{c}\text { Providing Personnel hygiene } \\
\text { care }\end{array}$ & 21 & .16 & .05 & \\
\hline & $\begin{array}{c}\text { Assisting with bladder, bowel } \\
\text { elimination }\end{array}$ & 56 & .44 & .13 & \\
\hline & $\begin{array}{l}\text { Communication with child/ } \\
\text { relative }\end{array}$ & 48 & .38 & .11 & \\
\hline & Collecting specimen & 39 & .30 & .09 & \\
\hline & Comfort measure & 41 & .32 & .1 & \\
\hline & Play therapy & 40 & .31 & .09 & \\
\hline & Assisting in examination & 40 & .31 & .09 & \\
\hline & $\begin{array}{l}\text {-Preparation of child prior to } \\
\text { surgery/any other procedure }\end{array}$ & 26 & .20 & .06 & \\
\hline & $\begin{array}{l}\text {-Receiving the pt. after } \\
\text { surgery/ }\end{array}$ & 69 & .54 & .16 & \\
\hline & -after procedure care & 55 & .43 & .13 & \\
\hline \multirow{6}{*}{$\begin{array}{c}\text { Indirect Care } \\
\text { Activities(Code } \\
\text { no. } 15-20)\end{array}$} & Documentation/Reporting & 149 & 1.18 & .35 & 28 \\
\hline & Preparing for procedure & 59 & .48 & .14 & \\
\hline & Helping for procedure & 45 & .35 & .10 & \\
\hline & Billing & 17 & .13 & .04 & \\
\hline & After care of articles & 28 & .22 & .06 & \\
\hline & $\begin{array}{c}\text { Communication with doctor/ } \\
\text { other staff }\end{array}$ & 101 & .8 & .24 & \\
\hline \multirow{3}{*}{$\begin{array}{c}\text { Unit Related } \\
\text { Activities (code } \\
\text { no. } 21-23 \text { ) }\end{array}$} & Housekeeping & 36 & 0.2 & .08 & 5 \\
\hline & -Supervising & 16 & 0.12 & .03 & \\
\hline & -Material Management & 22 & 0.17 & .05 & \\
\hline \multirow{6}{*}{$\begin{array}{c}\text { Miscellaneous } \\
\text { Activities (Code } \\
\text { no. 24-29) }\end{array}$} & Standing without work & 40 & .31 & .09 & 14 \\
\hline & -Talking among each other & 9 & .71 & .02 & \\
\hline & -Talking in phone & 17 & .13 & .04 & \\
\hline & -Going outside department & 23 & .18 & .05 & \\
\hline & -Eating food/snacks & 89 & .70 & .21 & \\
\hline & -Other personal activities. & 23 & .18 & .05 & \\
\hline
\end{tabular}

(Total no. of nurses' activities observed in one-week period)

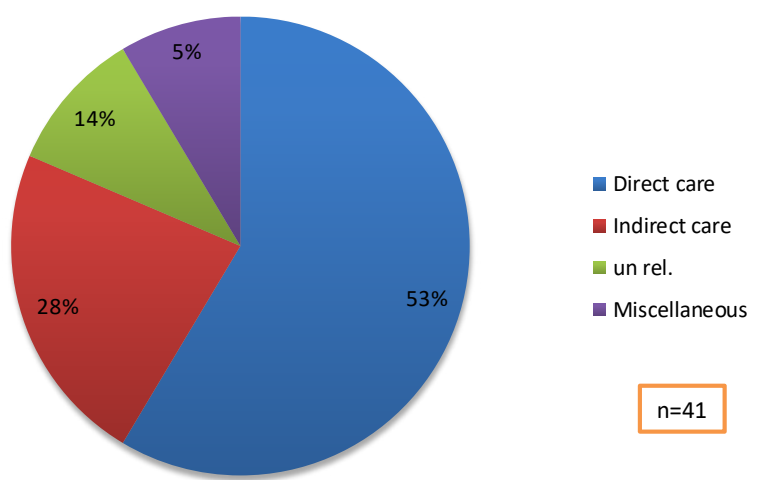

Figure 1.Pie Diagram Showing Proportion of Time Spent by Nurses in Various Activities in Pediatric Wards 
As shown in Table 2 and Fig 1, total 1511 activities were observed during seven days period in the pediatric units. Most of the nurse participants were engaged in direct care activities (53\%), followed by indirect care activities (28\%), miscellaneous activities (14\%) and least common were unit-related activities (5\%).

\section{Assessment of Proportion of Time Spent by Study Participants for Different Activities}

Table 3.Frequency and Proportion of Various Activities of Study Participants in the Morning Shifts of Pediatric In-patient Units

\begin{tabular}{|c|c|c|c|c|c|}
\hline $\begin{array}{l}\text { Group Of } \\
\text { Activities }\end{array}$ & Activities & Frequency & Average & $\begin{array}{c}\text { Relative Time } \\
\text { Proportion (hours) }\end{array}$ & $\begin{array}{c}\text { Total Time } \\
\text { Proportion (\%) }\end{array}$ \\
\hline \multirow{14}{*}{$\begin{array}{l}\text { Direct Activities } \\
\text { (Code no. 1-14) }\end{array}$} & Administration of medication & 89 & 1.14 & .34 & 64 \\
\hline & Monitoring of child & 94 & 1.20 & .36 & \\
\hline & Feeding through the tube & 51 & .65 & .19 & \\
\hline & Performing procedure & 53 & .67 & .20 & \\
\hline & $\begin{array}{c}\text { Providing Personnel hygiene } \\
\text { care }\end{array}$ & 13 & .16 & .50 & \\
\hline & $\begin{array}{c}\text { Assisting with bladder, bowel } \\
\text { elimination }\end{array}$ & 50 & .64 & .19 & \\
\hline & $\begin{array}{l}\text { Communication with child/ } \\
\text { relative }\end{array}$ & 24 & .30 & .09 & \\
\hline & Collecting specimen & 23 & .29 & .08 & \\
\hline & Comfort measure & 31 & .39 & .11 & \\
\hline & Play therapy & 28 & .35 & .10 & \\
\hline & Assisting in examination & 33 & .42 & .12 & \\
\hline & $\begin{array}{l}\text { Preparation of child prior to } \\
\text { surgery/any other procedure }\end{array}$ & 11 & .14 & .04 & \\
\hline & $\begin{array}{l}\text { Receiving the pt. after } \\
\text { surgery/ }\end{array}$ & 30 & .38 & .11 & \\
\hline & -after procedure care & 33 & .42 & .12 & \\
\hline \multirow{6}{*}{$\begin{array}{c}\text { Indirect Care } \\
\text { Activities(Code } \\
\text { no. 15-20) }\end{array}$} & Documentation/Reporting & 100 & 1.28 & .38 & 22 \\
\hline & Preparing for procedure & 32 & .41 & .12 & \\
\hline & Helping for procedure & 20 & .25 & .07 & \\
\hline & Billing & 7 & .08 & .02 & \\
\hline & After care of articles & 10 & .12 & .03 & \\
\hline & $\begin{array}{c}\text { Communication with doctor/ } \\
\text { other staff }\end{array}$ & 69 & .88 & .26 & \\
\hline \multirow{3}{*}{$\begin{array}{c}\text { Unit Related } \\
\text { Activities (code } \\
\text { no. } 21-23 \text { ) }\end{array}$} & Housekeeping & 9 & .01 & .03 & 2 \\
\hline & Supervising & 7 & .08 & .02 & \\
\hline & Material Management & 10 & .12 & .04 & \\
\hline \multirow{6}{*}{$\begin{array}{c}\text { Miscellaneous } \\
\text { Activities (Code } \\
\text { no. 24-29) }\end{array}$} & Standing without work & 15 & .19 & .05 & 12 \\
\hline & Talking & 5 & .06 & .02 & \\
\hline & Talking in phone & 8 & .10 & .03 & \\
\hline & Going outside department & 19 & .24 & .07 & \\
\hline & Eating food/snacks & 65 & .83 & .25 & \\
\hline & Other personal activities. & 13 & .16 & .05 & \\
\hline
\end{tabular}

(no. of nurses observed in one week period in morning shift)

As shown in Table 3, total 952 activities were observed during morning shifts during seven days period. Most of the nurse participants were engaged in direct care activities (64\%), followed by indirect care activities (22\%), miscellaneous activities (12\%) and unit related activities $(2 \%)$ in the morning shift in the pediatric units. 
Table 4.Frequency and Proportion of Various Activities of Study Participants in the Evening Shifts of Pediatric In-patient Units

\begin{tabular}{|c|c|c|c|c|c|}
\hline $\begin{array}{l}\text { Group Of } \\
\text { Activities }\end{array}$ & Activities & Frequency & Average & $\begin{array}{c}\text { Relative Time } \\
\text { Proportion (hours) }\end{array}$ & $\begin{array}{c}\text { Total Time } \\
\text { Proportion (\%) }\end{array}$ \\
\hline \multirow{14}{*}{$\begin{array}{l}\text { Direct Activities } \\
\text { (Code no. 1-14) }\end{array}$} & Administration of medication & 26 & 0.54 & .16 & $49 \%$ \\
\hline & Monitoring of child & 45 & 0.93 & .28 & \\
\hline & Feeding through the tube & 16 & 0.33 & .10 & \\
\hline & Performing procedure & 28 & 0.58 & .17 & \\
\hline & $\begin{array}{l}\text { Providing Personnel hygiene } \\
\text { care }\end{array}$ & 8 & 0.16 & .05 & \\
\hline & $\begin{array}{c}\text { Assisting with bladder, bowel } \\
\text { elimination }\end{array}$ & 6 & 0.12 & .04 & \\
\hline & $\begin{array}{l}\text { Communication with child/ } \\
\text { relative }\end{array}$ & 24 & 0.5 & .15 & \\
\hline & Collecting specimen & 16 & 0.33 & .10 & \\
\hline & Comfort measure & 10 & .28 & .06 & \\
\hline & Play therapy & 12 & .25 & .07 & \\
\hline & Assisting in examination & 7 & .14 & .04 & \\
\hline & $\begin{array}{l}\text { Preparation of child prior to } \\
\text { surgery/any other procedure }\end{array}$ & 15 & .31 & .09 & \\
\hline & $\begin{array}{l}\text { Receiving the pt. after } \\
\text { surgery/ }\end{array}$ & 39 & .82 & .24 & \\
\hline & after procedure care & 22 & .45 & .13 & \\
\hline \multirow{6}{*}{$\begin{array}{c}\text { Indirect Care } \\
\text { Activities(Code } \\
\text { no. } 15-20 \text { ) }\end{array}$} & Documentation/Reporting & 49 & 1.02 & .30 & $29 \%$ \\
\hline & Preparing for procedure & 27 & .56 & .16 & \\
\hline & Helping for procedure & 25 & .52 & .15 & \\
\hline & Billing & 10 & .20 & .06 & \\
\hline & After care of articles & 18 & .37 & .11 & \\
\hline & $\begin{array}{l}\text { Communication with doctor/ } \\
\text { other staff }\end{array}$ & 32 & .66 & .20 & \\
\hline \multirow{3}{*}{$\begin{array}{c}\text { Unit Related } \\
\text { Activities (code } \\
\text { no. } 21-23 \text { ) }\end{array}$} & Housekeeping & 27 & .56 & .17 & $9 \%$ \\
\hline & Supervising & 9 & .18 & .06 & \\
\hline & Material Management & 12 & .25 & .07 & \\
\hline \multirow{6}{*}{$\begin{array}{c}\text { Miscellaneous } \\
\text { Activities (Code } \\
\text { no. } 24-29 \text { ) }\end{array}$} & Standing without work & 25 & .52 & .15 & $13 \%$ \\
\hline & Talking & 4 & .08 & .02 & \\
\hline & Talking in phone & 9 & .18 & .05 & \\
\hline & Going outside department & 4 & .83 & .02 & \\
\hline & Eating food/snacks & 24 & .5 & .15 & \\
\hline & Other personal activities. & 10 & .2 & .06 & \\
\hline
\end{tabular}

(No. of nurses observed in one week period in evening shift)

As shown in Table 4, total 559 activities were observed in the evening shifts during seven days period. Nurse participants were involved more in the direct care activities (49\%) followed by indirect activities (29\%), miscellaneous activities (13\%) and unit-related activities (9\%).

\section{Discussion}

According to a study by Abbey et al., ${ }^{7}$ the major activity groups for the ICU nurses were: 'direct care' 1857 activities and $40.5 \%$ of the time, 'indirect care' 986 activities and $32.4 \%$ of their time, 'personal' activities 140 activities and
$21.9 \%$ of their time and 'unit related' 98 activities and 5\% of their time. The ICU nurses undertook two activities simultaneously for $43 \%$ of their study time frame. The present study showed similar results in that most of the nurses were engaged in direct care activities (53\%), followed by indirect care activities (28\%), miscellaneous activities $(14 \%)$ and least common were unit related activities (5\%).

Vasta and Gupta found that nurses working in orthopedic ward of a tertiary care hospital in India spent $7 \%$ of time for patient care basic and $17 \%$ of time for patient care complex activities. Other activities included off-station (24\%), 
clerical (8\%), administration (7\%), maintaining supplies and equipment (3\%), housekeeping ( $2 \%$ ) and non-productive (32\%). After the intervention on collaboration between nursing services and nursing education, the activities changed as patient care basic (10\%), patient care complex $(37 \%)$, off station (9\%), and clerical (11\%), maintaining supplies and equipment (4\%), housekeeping (3\%) and non-productive (15\%). Whereas findings related to present study which was done in pediatric wards shows most of the nurse's engaged in direct care activity (53\%) followed by indirect activities (22\%), miscellaneous activities (12\%) and unit-related activities (2\%).

\section{Conclusion}

The nursing personnel in pediatric ward spent most of the time in direct care patient activities more than indirect care patient activities. And the least common time was spent in unit-related activities in pediatric in-patient units. Nurses in pediatric wards spent almost same proportion of time in different activity groups and direct care activity was higher in both shifts. The study drew implications that the curriculum in the nursing courses must incorporate time management strategies, especially in the pediatric settings and that the students must be taught regarding effective organization of patient care activities in their clinical practices.

Conflict of interest: None

\section{References}

1. Urden LD, Rode JL. Work-sampling: a decision-making tool for determining resources and work redesign. Journal of Nursing Adm 1997; 27(9); 34-41.

2. Duffield C, Wise W. Tell me what we do. Using work sampling to find answer. Aust Journal of Advance Nursing 2003; 20(3):19-23.

3. Unruth LY. Employment condition at the bed side: a cause of and solution to the RN shortage, Journal of Nursing Administration 2005: 35(1): 11-15.

4. Duffield C, Wise W. Tell me what we do. Using work sampling to find answer. Aust Journal of Advance Nursing 2003; 20(3):19-23.

5. Munyisia EN, Hailey D. How nursing staff spend their time on activities in a nursing home: an observational study. Journal Of Advance Nursing 2011. Available from http:/www.uow.edu/ ping/publication/Muniyisia2012. pdf.

6. Criwk-Morvee, $\mathrm{MH}$, Hughes $\mathrm{CM}$, Nursing time allowance and other consideration for staffing. Nursing Health Sci 2005; 7(2): 126-33.

7. Abbey M, Caboyer W, Mitchell M. Understanding the work of intensive care nurses: a time and motion study. Australia Critical Care 2012; 25(1):13-22.

Date of Submission: 2017-08-01

Date of Acceptance: 2017-10-04 